any): phosphate (100 $\mathrm{mg} ; \mathrm{pH} 2$ ), thiosulphate (100 mg; pH 3), fluoride (100 mg; $\mathrm{pH} \mathrm{2}$ ), tartrate (550 mg; pH 3), citrate (550 mg; pH 3), lead(II) (100 mg), aluminium (100 mg; citrate), antimony(III) (50 mg; tartrate), zirconium (100 mg; tartrate, citrate), titanium (50 mg; tartrate), molybdate (100 mg; tartrate), tungsten(VI) (100 mg; tartrate).

The following ions do not interfere at $\mathrm{pH} 2$ even in 100-fold amounts: sulphate, bromide, tartrate, citrate, zinc, cadmium, magnesium, calcium, strontium, barium, manganese(II), beryllium and ura$\operatorname{nium}(\mathrm{VI})$.

The relative standard deviation has been found to be in the range of $0.5-0.75 \%$.

Dr. G. S. Manku

Hans Raj College

Delhi-7, India

\section{N-Chloroacetamide as a Redox Reagent}

\section{Potentiometric Determination of Common Reductants and Hydrazines}

N-Chloracetamid als Redoxreagens. Potentiometrische Bestimmung üblicher Reduktionsmittel und Hydrazine

Balwant Singh*, S. C. Nistandra** and Batbir Chand Verma

Department of Chemistry, Punjabi University, Patiala, India

Received November 30, 1971

In a previous paper [1] $\mathrm{N}$-chloroacetamide was described as a redox reagent for the determination of thiourea and its organic derivativesin sulphuric acid medium. In the present study, the use of N-chloroacetamide as a redox reagent has been extended to the determination of common reductants (arsenious oxide, potassium iodide, potassium thiocyanate, stannous chloride or thallous nitrate) and hydrazines (4-phenylsemicarbazide hydrochloride, p-methoxybenzalsemicarbazone, benzalsemicarbazone, phenylhydrazine hydrochloride, 2:4-dinitrophenylhydrazine, vanillinsemicarbazone, semicarbazide hydrochloride, hydrazine sulphate, benzalazine or $\beta$ acetylphenylhydrazine) in hydrochloric acid medium by a potentiometric method.

* Present address: Department of Chemistry, Panjab University, Chandigarh, India.

** Present address: Department of Chemistry, D. A. V College, Chandigarh, India.

\section{Experimental}

A known weight of each compound was taken in a beaker; sufficient water and enough of hydrochloric acid were added to keep normality of the solution at 2.5 to $4.0 \mathrm{~N}$ and its volume to $80 \mathrm{ml}$. Each titration mixture was titrated potentiometrically with the standard $0.1 \mathrm{~N} \mathrm{~N}$-chloroacetamide solution at room temperature, except thallous nitrate which was titrated at $60^{\circ} \mathrm{C}$.

The potentiometric titrations were performed with platinum wire electrode as an oxidation-reduction electrode and saturated calomel electrode as reference electrode. The progress of the reaction was studied with Mullard potentiometer. A sharp jump in potential was observed at the equivalence point in each titration. A series of potentiometric titrations was performed with different amounts of each compound.

From the volume of the oxidant used corresponding to the equivalence point in each titration, the amount of each compound was calculated. 10 to $100 \mathrm{mg}$ of the above mentioned compounds could be determined with a maximum deviation of $0.8 \%$. The hydrazine group in hydrazine and its organic derivatives is oxidised to nitrogen with a fourelectron change.

\section{Reference}

1. 'Singh, B., Nistandra, S. C., Verma, B. C.: Z. Anal. Chem. 257, 348 (1971).

Dr. Balbir Chand Verma Ph. D

Department of Chemistry

Punjabi University

Patiala, India

\section{1,5-Di- $\beta$-naphthylthiocarbazone as an Extractive Indicator for the Determination of Cadmium with EDTA}

1,5-Di- $\beta$-naphthylthiocarbazon als Extraktionsindicator für die Bestimmung von Cadmium mit ÄDTA

\section{S. K. Sindhwant, Y. Dutr and R. P. Singh}

Department of Chemistry, University of Delhi, Delhi-7, India

Received November 22, 1971

During investigations of the colour reactions with 1,5-di- $\beta$-naphthylthiocarbazone (HDNZ), it has been found that cadmium, lead [1] and zinc [2] give coloured complexes which are extractable into chloroform and carbon tetrachloride. In the case of cadmium the colour reaction is very sensitive. It was therefore thought worth while to carry out the complexometric titration of cadmium with EDTA using 1,5-di- $\beta$-naphthylthiocarbazone. 